\title{
Screening of Biocontrol Agents against Pathogens causing Diseases of Brinjal
}

\author{
G.K. Upamanya ${ }^{1 *}$ and Pranab Dutta ${ }^{2}$ \\ ${ }^{1}$ SCS College of Agriculture, ${ }^{2}$ College of Agriculture, Assam Agricultural University, \\ Jorhat, India
}

*Corresponding author

\begin{abstract}
A B S T R A C T
Keywords

Rhizoctonia solani,

Fusarium solani,

Alternaria

melongenae,

Sclerotinia

sclerotiorum

Phomopsis vexans,

Dual culture

Article Info

Accepted:

10 May 2019

Available Online:

10 June 2019

Brinjal growers of Assam completely depend on the chemocentric cultivation practices to combat the crop diseases, which increases the cost of cultivation and affect the consumers with pesticides residues. Moreover, excessive use of a wide range of fungicides has resulted harmful effect to the environment and increased the resistant pathogen populations. Development of an alternative eco-friendly disease management module for sustainable crop production is the need of the hour. Present study was conducted to find out the effective biocontrol agents against important pathogens of brinjal showed that out of six (6) indigenous biocontrol agents viz. Beauveria bassiana, Metarhizium anisopliae, Trichoderma asperellum, T. harzinum, Paecilomyces lilacinus and Gliocladium virens, T. harzianum showed maximum inhibition of Rhizoctonia solani (74.44\%), Fusarium solani (70.68\%), Alternaria melongenae (72.48\%), Sclerotinia sclerotiorum $(69.15 \%)$ and Phomopsis vexans (77.82). T. asperellum and $G$. virens also showed significantly better inhibition against these pathogens causing diseases in brinjal over B. bassiana, M. anisopliae and $P$. lilacinus. The present study showed that T. harzianum, T. asperellum and $G$. virens can be used for preparation of bioformulation for management of diseases of brinjal.
\end{abstract}

\section{Introduction}

Brinjal (Solanum melongena) is one of the most important vegetables in South and South-East Asia. In India, it is grown on over 669,000 ha with a production of 12400 thousand MT, while in Assam brinjal is grown over 17670 ha with a production of 286.43 Thousand MT (Ministry of Agriculture \& Farmers' Welfare, GOI, 2017). The productivity of brinjal in Assam is 16.20
MT/ha which is less as compared to the national productivity (18.50 MT/ha). The lower productivity of this vegetable in Assam may be due to attack of diseases. The major diseases of brinjal observed during the year 2014-15 and 2015-16 in Barpeta and Jorhat district of Assam were damping off (Rhizoctonia solani), leaf spot (Alternaria melongenae), Phomopsis blight and fruit rot (Phomopsis vexans), Sclerotinia blight (Sclerotinia sclerotiorum) and wilt (Fusarium 
soani). Farmers generally depend on the fungicides like Bavistin (Carbendazim 50WP), Indofil M-45 (Mancozeb), Ridomil MZ (Metalaxyl 8\% + Mancozeb 64\%) for management of these diseases. However, intensified utilization of fungicides has resulted in harmful effect on non-target organisms, the development of resistance races of the pathogens, and the possible carcinogenicity (Vinale et al., 2008; Doley and Jite, 2012). Indiscriminate use of synthetic fungicides leads to environmental pollution, development of resistance in pathogens and adverse effects on beneficial insects, wild life, human beings, and ultimately lead to ecological imbalance. In this context, biological control is considered as an alternative and ecofriendly way to control plant diseases and reduce the chemical in agriculture. Biological control assumes major importance for suppressing the crop diseases and pests with bio control agents like Bacillus subtilis, Gliocladium spp, Trichoderma spp, Pseudomonas fluorescens, Beauveria bassiana, Metarhizium anisopliae, Paecilomyces lilacinus etc. Few success stories have been reported by earlier worker (Abdullah et al., 2008; Najar et al., 2011; Kamala and Indira, 2014) for the management of wilt, Pythium and Phytophthora damping off etc. by biocontrol agents like Trichoderma sp, Pseudomonas fluorescens, Bacillus sp etc. Several fungi are known to antagonize numerous fungal pathogens and among them, Trichoderma spp are found effective in reducing major soil borne disease of vegetable crops particularly the solanaceous vegetables. The current study was conducted in vitro to assess the antagonistic activity of indigenous bio control agents viz. Beauveria bassiana, Metarhizium anisopliae, Trichoderma asperellum, T. harzinum, Paecilomyces lilacinus and Gliocladium virens against the major pathogens of brinjal found in Barpeta and Jorhat district of Assam.

\section{Materials and Methods}

The important diseases of brinjal observed in Experimental Farm, Department of Horticulture, AAU, Jorhat and Demonstration Farm of Krishi Vigyan Kendra, Barpeta were damping off of seedling caused by Rhizoctonia solani, Alternaria leaf spot by Alternaria melongenae, Phomopsis blight and fruit rot by Phomopsis vexans, Sclerotinia blight by Sclerotinia sclerotiorum and Fusarium wilt caused by Fusarium solani. Pure culture of the pathogens causing diseases of brinjal were obtained in potato dextrose agar (PDA) media using the methods followed by the earlier worker viz. Alternaria melongenae(Johnston and Booth, 1983), Rhizoctonia solani (Jiskani et al., 2007), Sclerotiniasclerotiorum (Stevens, 1974), Phomopsis vexans (Namo Das et al., 2014), Fusarium solani (Sahar et al., 2013). Biocontrol agents like Beauveria bassiana, Metarhizium anisopliae, Trichoderma asperellum, T. harzianum, Paecilomyces lilacinus and Gliocladium virens were collected from the culture bank maintained in Nanolab of Department of Plant Pathology, AAU, Jorhat. In vitro antagonistic behavior of bio control agents against counterpart pathogen of brinjal viz., R.solani, $A$. melongenae, P.vexans, S. sclerotiorum and F.solani were studied using standard dual culture method (Dennis and Webster, 1971) with three replicates. Percentage growth inhibition was calculated by using the following formula.

$$
\text { Inhibition }(\%)=\left(\frac{\mathrm{C}-\mathrm{T}}{\mathrm{C}}\right) \times 100
$$

Whereas, $\mathrm{C}=$ Diameter of fungus colony (cm) in control plate, $\mathrm{T}=$ Diameter of fungus colony $(\mathrm{cm})$ in treated plate.

The pathogen and bio control agent combination studied were as follows: 


\begin{tabular}{|c|c|}
\hline Combination-1 & Combination-2 \\
\hline Rhizoctonia solani alone & Fusarium solanialone \\
\hline R. solani+ Beauveria bassiana & F. solani+ B. bassiana \\
\hline R. solani+Metarhizium anisopliae & F. solani+ M. anisopliae \\
\hline R. solani+ Trichoderma asperellum & F. solani+ T. asperellum \\
\hline R. solani+ T. harzinum & F. solani+ T. harzianum \\
\hline R. solani+ Paecilomyces lilacinus & F. solani+ P. lilacinus \\
\hline R. solani+ Gliocladium virens & F. solani+ G. virens \\
\hline Combination-3 & Combination-4 \\
\hline Alternaria melongenaealone & Sclerotiniasclerotiorumalone \\
\hline A. melongenae+ B. bassiana & S. sclerotiorum+ B. bassiana \\
\hline A. melongenae+ M. anisopliae & S. sclerotiorum+ M. anisopliae \\
\hline A. melongenae+ T. asperellum & S. sclerotiorum+ T. asperellum \\
\hline A. melongenae+ T. harzinum & S. sclerotiorum+ T. harzinum \\
\hline A. melongenae+ $P$. lilacinus & S. sclerotiorum+ P. lilacinus \\
\hline A. melongenae+ G. virens & S. sclerotiorum+ G. virens \\
\hline \multicolumn{2}{|l|}{ Combination-5 } \\
\hline \multicolumn{2}{|l|}{ Phomopsis vexans alone } \\
\hline \multicolumn{2}{|l|}{$P$. vexans $+B$. bassiana } \\
\hline \multicolumn{2}{|l|}{ P. vexans + M. anisopliae } \\
\hline \multicolumn{2}{|l|}{$P$. vexans $+T$. asperellum } \\
\hline \multicolumn{2}{|l|}{$P$. vexans $+T$. harzinum } \\
\hline \multicolumn{2}{|l|}{$P$. vexans $+P$. lilacinus } \\
\hline P. vexans + G. virens & \\
\hline
\end{tabular}

\section{Results and Discussion}

The data presented in the Table 1 revealed that all the biocontrol agents inhibited the growth of pathogens. B. bassiana, $M$. anisopliae and $P$. lilacinus were found to be less efficient in inhibiting the growth of pathogens of brinjal. Out of two entomopathogens, B.bassiana was found to be the superior in inhibiting the growth and found to inhibit 56.67 per cent radial growth of P.vexans and 56.32 per cent of F.solani. $M$. anisopliae exhibited 37.77 per cent inhibition of radial growth of $R$. solani which was the lowest among all the biocontrol agents tested in the experiment. The nematopathogenic fungi $P$. lilacinus exhibited the radial growth of $34.30 \mathrm{~mm}$ with 61.66 per cent growth inhibition against A.melongenae which was statistically superior over $B$. bassiana
(49.83\%), M. anisopliae (44.51\%) and control. Mycopathogens T. harzianum, $T$. asperellum and $G$. virens showed better inhibition of growth of brinjal pathogens over B. bassiana, M. anisopliae and P. lilacinus. T. harzianum showed the highest inhibition of radial growth of $R$. solani (74.44\%) followed by $T$. asperellum $(65.56 \%)$ and G. virens $(65.55 \%)$ (Fig. 1\&2). The highest inhibition of radial growth of $F$. solani was noticed with T. harzianum (70.68\%) followed by $T$. asperellum $(68.71 \%)$ and $G$. virens $(61.41 \%)$. However, there was no significant difference in the radial growth of $F$. solani with $B$. bassaina, G. virens and $P$. lilacinus. Lowest radial growth of $A$. melongenae was observed in dual culture with $T$. harzianum $(24.30 \mathrm{~mm})$ and showed $72.48 \%$ inhibition in the growth of the pathogen followed by $T$. asperellum $(71.00 \%)$ and G. virens $(71.00 \%)$. In the dual 
culture experiment, T. harzianum (69.15\%),T. asperellum $(69.99 \%)$ and G. virens $(63.63 \%)$, showed statistically similar efficiency in inhibiting the radial growth of Sclerotinia sclerotiorum and found superior over other biocontrol agents. T. harzianum showed marked inhibition $(77.82 \%)$ against $P$. vexans followed by $T$. asperellum $(72.41 \%)$ and $G$. virens $(71.26 \%)$. It was observed from the entire dual culture experiment that T.harzianum was the most efficient in inhibiting the radial growth of all the pathogens of brinjal followed by $T$. asperellumand $G$. virens. The mycopathogen, $T$. harzianum was found to be the best among all the BCA tested. The entomopathogen, $B$. bassiana was found to be better than $M$. anisopliae in inhibiting the pathogen in dual culture. Similarly, nematopathogen, $P$. lilacinus was also recorded better inhibition potential than M.anisopliae against brinjal pathogen in dual culture. Ghosh and Chakraborty (2012) found the isolate BB-1 of B.bassiana as class I antagonist i.e. completely overgrowth the pathogen Colletotrichum gloeosporioides, the causal organism of anthracnose of Roulvolfia serpentina in dual culture experiment. The efficiency of B. bassiana and P. lilacinus was also reported against Macrophomatheicola by Mareeswaran et al., (2016) in dual culture. Antibiosis and mycoparasitism may be the reason behind the inhibition of radial growth of the pathogens by $B$. bassiana in dual culture. The highest percentage of growth inhibition of Rhizoctonia solani by $T$. harzianum was observed and was followed by T. asperellum in our study. Similar findings of interaction of Trichodermasp (T. hamatum $\mathrm{T}$ 614, T. hamatum T 612, T.harzianum T 447, T. harzianum $\mathrm{T} 969, T$. virens $\mathrm{T} 523$ and Trichodermasp T) with $R$. solani were recorded by Hajieghrari et al., 2008. The inhibition of radial growth of two interacting organisms in dual culture has been attributed to secretion of extracellular hydrolytic enzymes (Scirmbock et al., 1994), production of antibiotics (Howel, 1998) as well as some cell wall degrading enzymes such as chitinase, glucanase which destroy cell wall integrity (Elad, 2000). T. harzianum and T. asperellum were found to be the superior in inhibiting the radial growth of Fusarium solani with inhibition of 70.68 per cent and 68.71 per cent respectively in dual culture. Similar results were also obtained by Sarker et al., 2013 they found 75.75 per cent inhibition of $F$. oxysporum f.sp lycopersici with T. harzianum. Sundar et al., 1995 and Deshmukh and Raut, 1992 reported that $T$. harzianum grew over the colonies of $F$. oxysporum. Chabbi and Matrod (2002) reported 77 per cent growth inhibition of $F$. oxysporum with $T$. harzianum. Marked inhibition of mycelium of Alternaria melongeane was recorded with T. harzianum (72.48\%) followed by $T$. asperellum $(71 \%)$ in the present investigation. Ambuse (2012) also observed $76.66 \%$ inhibition of A. tenuissima with $T$. harzianum in dual culture.

The result was almost in conformity with Ibrahim El Gali (2015) who reported 83.3 per cent inhibition of $A$. alternate with $T$. harzianum at 7 days of inoculation. However, decreased growth inhibition of $A$. solani was noticed with $T$. viride $(34.76 \%)$ in dual culture by Tapwal et al., (2011). The inhibition of A. alternata in dual culture with T. harzianum was reported as 72.2 per cent which was similar to our observation (Tagaram et al., 2015). Significant differences $(p<0.05)$ among the mycopathogens, nematopathogen and entomopathogens were observed in respect of percentage of radial growth inhibition of S.sclerotiorum in present dual culture experiment. The best biocontrol agent against $S$. sclerotiorum was $T$. asperellum (69.99\%) and was followed by $T$. harzianum (69.15\%) and G.virens (63.63\%). 
Table.1 Radial growth inhibition (\%) of pathogens of brinjal by different bio control agents

\begin{tabular}{|c|c|c|c|c|c|c|c|c|c|c|}
\hline \multirow[t]{2}{*}{ BCA } & \multicolumn{2}{|c|}{ Rhizoctonia solani } & \multicolumn{2}{|c|}{ Fusarium solani } & \multicolumn{2}{|c|}{ Alternaria melongenae } & \multicolumn{2}{|c|}{ Sclerotinia sclerotiorum } & \multicolumn{2}{|c|}{ Phomopsis vexans } \\
\hline & $\begin{array}{l}\text { Radial } \\
\text { growth } \\
(\mathrm{mm})\end{array}$ & $\begin{array}{c}\text { Growth } \\
\text { inhibition } \\
(\%)\end{array}$ & $\begin{array}{c}\text { Radial } \\
\text { growth } \\
(\mathrm{mm})\end{array}$ & $\begin{array}{c}\text { Growth } \\
\text { inhibition } \\
(\%)\end{array}$ & $\begin{array}{c}\text { Radial } \\
\text { growth } \\
(\mathrm{mm})\end{array}$ & $\begin{array}{c}\text { Growth } \\
\text { inhibition } \\
(\%)\end{array}$ & $\begin{array}{c}\text { Radial } \\
\text { growth } \\
\text { (mm) }\end{array}$ & $\begin{array}{c}\text { Growth } \\
\text { inhibition } \\
(\%)\end{array}$ & $\begin{array}{c}\text { Radial } \\
\text { growth } \\
\text { (mm) }\end{array}$ & $\begin{array}{c}\text { Growth } \\
\text { inhibition } \\
(\%)\end{array}$ \\
\hline Control & $90.00^{\mathrm{a}}$ & - & $86.30^{\mathrm{a}}$ & - & $88.30^{\mathrm{a}}$ & - & $83.30^{\mathrm{a}}$ & - & $87.00^{a}$ & - \\
\hline B. bassiana & $40.00^{c}$ & 55.55 & $37.70^{c}$ & 56.32 & $44.30^{b}$ & 49.83 & $37.30^{b}$ & 55.22 & $37.00^{b}$ & 56.67 \\
\hline M. anisopliae & $56.00^{b}$ & 37.77 & $49.70^{b}$ & 42.41 & $49.00^{b}$ & 44.51 & $39.00^{b}$ & 53.18 & $40.00^{b}$ & 54.02 \\
\hline T. asperellum & $31.00^{\mathrm{cd}}$ & 65.56 & $27.00^{\mathrm{de}}$ & 68.71 & $25.60^{d}$ & 71.00 & $25.00^{\mathrm{d}}$ & 69.99 & $24.00^{\mathrm{cd}}$ & 72.41 \\
\hline T. harzianum & $23.00^{d}$ & 74.44 & $25.30^{\mathrm{e}}$ & 70.68 & $24.30^{d}$ & 72.48 & $25.70^{d}$ & 69.15 & $19.30^{\mathrm{d}}$ & 77.82 \\
\hline P. lilacinus & $38.00^{\mathrm{d}}$ & 57.78 & $40.70^{c}$ & 52.83 & $34.30^{c}$ & 61.16 & $34.30^{\mathrm{bc}}$ & 58.82 & $35.70^{b}$ & 58.97 \\
\hline G. virens & $31.00^{\mathrm{cd}}$ & 65.55 & $33.30^{\mathrm{cd}}$ & 61.41 & $25.60^{\mathrm{e}}$ & 71.00 & $30.30^{\mathrm{cd}}$ & 63.63 & $25.00^{c}$ & 71.26 \\
\hline $\operatorname{SEd}( \pm)$ & 4.40 & & 3.60 & & 2.90 & & 2.70 & & 2.30 & \\
\hline CD at 0.05 & 9.10 & & 7.40 & & 6.01 & & 5.60 & & 4.70 & \\
\hline
\end{tabular}

Data are mean of three replications 
Fig.1 Radial growth inhibition of pathogens causing diseases of brinjal by different biocontrol agents
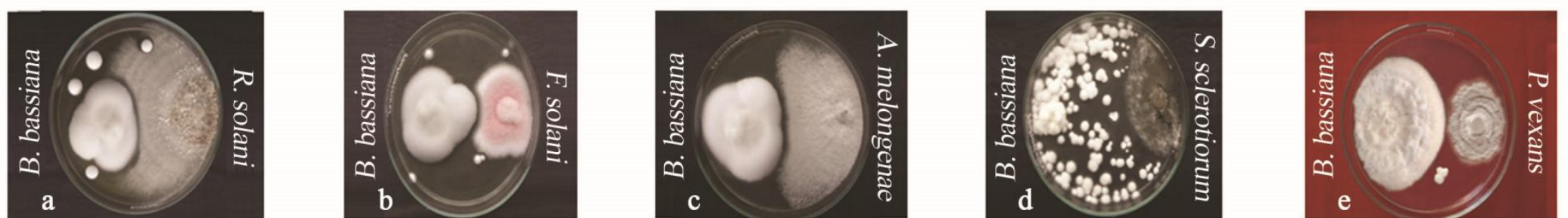

a. B. bassiana + R. solani, b. B. bassiana + F. solani, c. B. bassiana + A. melongenae, d. B. bassiana + S. sclerotiorum, e. B. bassiana $+P$. vexans
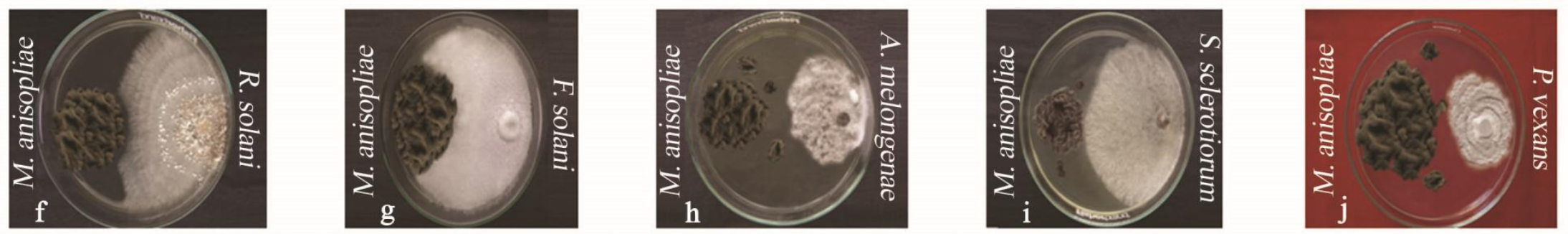

f. M. anisopliae + R. solani, g. M. anisopliae +F. solani, h. M. anisopliae + A. melongenae, i. M. anisopliae + S. sclerotiorum, j. M. anisopliae $+P$. vexans
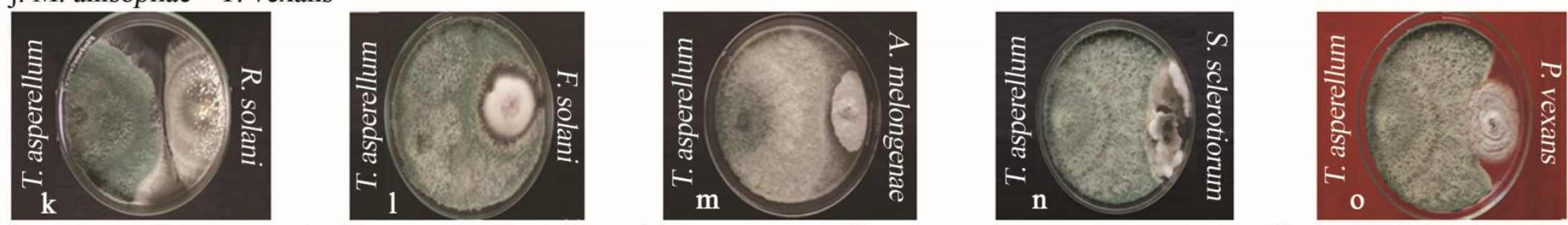

k. T. asperellum $+R$. solani, 1. T. asperellum + F. solani, m. T. asperellum + A. melongenae, $\mathrm{n} . T$. asperellum $+S$. sclerotiorum, o. T. asperellum + P. vexans 
Fig.2 Radial growth inhibition of pathogens causing diseases of brinjal by different biocontrol agents
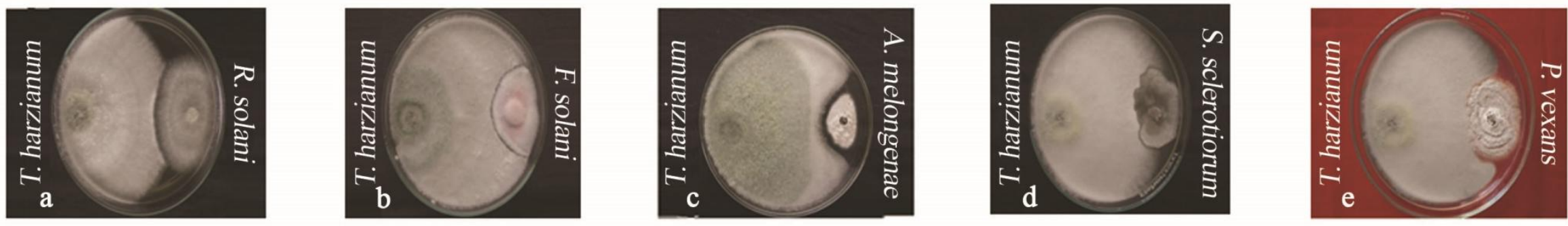

a. T. harzianum $+R$. solani, b. T. harzianum + F. solani, c. T. harzianum + A. melongenae, d. T. harzianum $+S$. sclerotiorum, e. T. harzianum + P. vexans
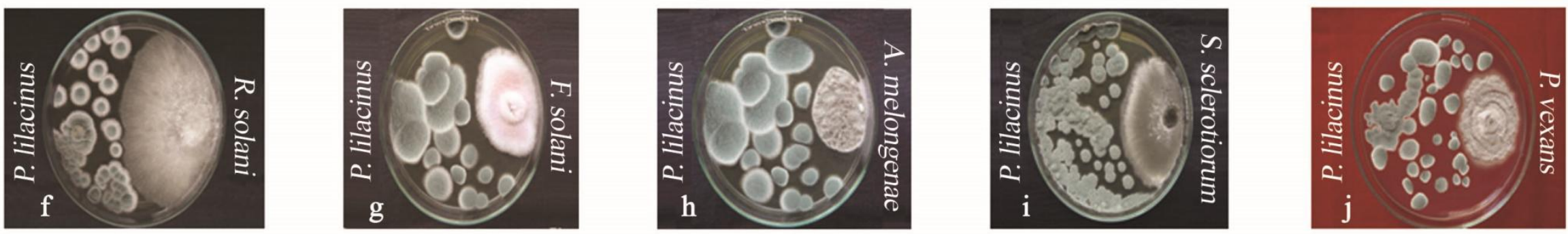

f. P. lilacinus + R. solani, g. P. lilacinus + F. solani, h. P. lilacinus + A. melongenae, i. P. lilacinus + S. sclerotiorum, j. P. lilacinus $+P$. vexans
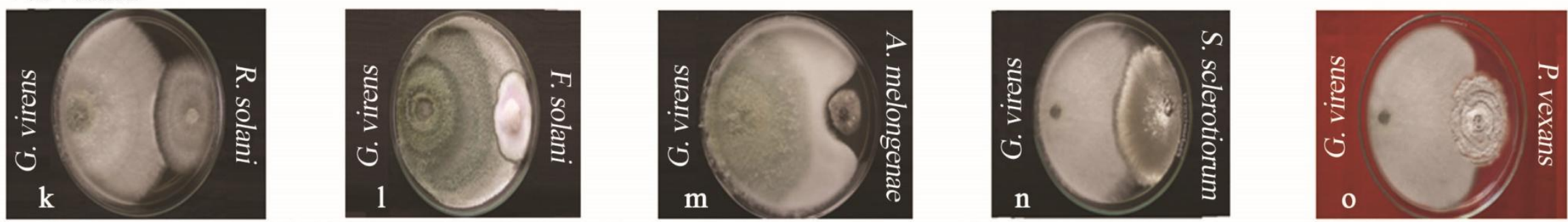

k. G. virens $+R$. solani, 1. G. virens + F. solani, m. G. virens + A. melongenae, n. G. virens $+S$. sclerotiorum, o. G. virens $+P$. vexans 
The similar trends of results were obtained by Castillo et al., (2011) against $S$. sclerotiorum with $T$. harzianum strain $\mathrm{T}_{4}$ and $T$. asperellum strain $T_{1}$ with 60.3 per cent and 57.6 per cent inhibition respectively in dual culture. Shaigan et al., (2008) also observed better inhibition of $T$. viride against Sclerotium rolfsii than $T$. harzianum, $T$. hamatum, $T$. longibrachiatum and $T$. paraseramosum. The higher inhibition of the pathogen by biocontrol agents in dual culture might be due to antagonistic competition for space and nutrients (Shaigan et al., 2008). T. harzianum was found to be the best among all BCA in inhibiting the mycelial growth of P.vexans (77.82\%). However, T. asperellum $(72.41 \%)$ was also at par with $T$. harzianum in inhibiting the growth of $P$. vexans. The present findings were found in agreement with the report of Namo Das et al., (2014) who reported 84.00 per cent inhibition of $P$. vexans with $T$. viride and 78.22 per cent with T. harzianum.

The present study concludes that $T$. harzianumis the best biocontrol agent against the pathogens causing diseases of brinjal followed by $T$. asperellum, Gliocladium virens. The data obtained from this experiment could provide a way for biological management of brinjal diseases by developing a bioformulation using the best biocontrol agents.

\section{References}

Abdullah MT, Ali AY and Suleman P. 2008.Biological control of Sclerotinia sclerotiorum (Lib.) de Bary with Trichoderma harzianum and Bacillus amyloliquefaciens. Crop Prot. 27 (10): 1354-1359.

Ambuse MG, Chatage VS and Bhale UN. 2012. Influence of Trichoderma spp against Alternaria tenuissima inciting leaf spot of Rumex acetosa L. Biosci. Discov. 3 (2): 259-262.

Castillo FDH, Padilla AMB, Morales GG,
SillerMC, Herrera RR, Gonzales CNA and Reyes FC 2011. In vitro antagonist action of Trichoderma strains against Sclerotinia sclerotiorum and Sclerotium cepivorum. Am. J. Agricul. Biol. Sci. 6 (3): 410-417.

Chaabi SA and Matrod L. 2002. Laboratory study to evaluate efficacy of different Trichoderma spp. isolates on some soilborne pathogenic fungi. AJPP.20 (2): 77-83.

Dennis C and Webster J. 1971. Antagonistic properties of species, groups of Trichoderma. Production of non-volatile antibiotics. Trans Br. Mycol. Soc. 57: 2539.

Deshmukh PP. and Raut JG. 1992. Antagonism by Trichoderma sp. on five plant pathogenic fungi. New Agriculturist. 3 (2): 127-130.

Doley K and Jite PK. 2012. In-Vitro efficacy of Trichoderma virideagainst Sclerotium rolfsii and Macrophomina phaseolina. Not. Sci. Biol. 4: 39-44.

Elad Y. 2000. Biological control of foliar pathogens by meand of Trichoderma harzianum and potential modes of action. Crop Protec. 19: 709-714.

Ghosh SKand Chakraborty N. 2012. In vitro biological control of Colletotrichum gloeosporioides, causal organism of anthracnose of sarpagandha (Roulvolfia serpentina). Agric. Biol. J. N. Am. 3 (8): 306-310.

Hajieghrari B, Torabi-Giglou M, Mohammadi MR. and Davari M. 2008. Biological potential of some Iranian Trichoderma isolates in the control of soil borne plant pathogenic fungi. Afr. J. of Biotechnol. 7: 967-972.

Howel CR. 1998. The role of antibiosis in biocontrol. In: Trichoderma and Gliocladium: Enzymes. Biological Control and Commercial Applications (Vol 2), Taylor and Francis, London. pp 173-184.

Ibrahim El-Gali Z. 2015. Antagonistic compatibility in vitro of Trichoderma harzianum against Alternaria alternata on Ceratonia siliqua. EJPMR, 2(2): 30-44.

Jiskani MM, Pathan MA Wagan KH, Imran M and Arbo H. 2007. Studies on the control of tomato damping-off disease caused by Rhizoctonia solani Kuhn. Pak. J. Bot.39 
(7): 2749-2754.

Johnston A and Booth C. 1983. Plant Pathologist Pocket Book. Commonwealth Mycological Institute, Kew, Surrey, England, pp. 439.

Kamala T and Indira S. 2014. Molecular characterizati on of Trichoderma harzianum strains from Manipur and their biocontrol potential against Pythium ultimum. IJCMAS. 3 (7): 258-270.

Mareeswaran J, Nepolean P, Jayanthi R, Samuel Asir RP and Radhakrishnan B. 2016. Bioefficacy of efficient entomopathogenic fungus against branch canker pathogen (Macrophoma theicola) in tea plantations of Southern India. Indian J. Agr. Sci. 86 (2): 242-246.

Najar AG, Ali A, Masoodi L and Khar MS. 2011. Evaluation of native biocontrol agents against Fusarium solanif.sp. melongenae causing wilt disease of brinjal in Kashmir. J. Phytol. 3 (6): 31-34.

Namo Das S, Sarma TC and Tapadar SA. 2014. In vitro evaluation of fungicides and two species of Trichoderma against Phomopsis vexans causing fruit rot of brinjal (Solanum melongena L.). Int. J. of Sci. and Res.: 4 (9): 1-3.

Sahar P, Sahi ST, Jabbar A, Rehman A, Kashif R and Hannan A. 2013. Chemical and biological management of fusarium oxysporum f.sp melongenae. Pak. J. Phytopathol. 25 (02): 155-159

SarkerAM, Sultana N, Islam MR, Rashid M and Bhuian ZR. 2013. Efficacy of some rhizosphere microorganisms in controlling Fusarium wilt of tomato (Lycopersicon esculentum). The Agriculturists 11(2): 96103.
Schirmbock M, Lorito M, Wang YL, Hayes CK Arisan-Atac I, Scala F., Harman, G.E. and Kubicek, C.P. 1994. Parallel formation and synergism of hydrolytic enzymes and peptaibol antibiotics, molecular mechanism involved in the antagonistic action of Trichoderma harzianum against phytopathogenic fungi. Appl. Environ. Microbiol.60: 4364-4370.

Shaigan S, Seraji A and Moghaddam SAM. 2008. Identification and investigation on antagonistic effect of Trichoderma spp. on tea seedlings white foot and root rot (Sclerotium rolffsiSacc) in vitro condition. Pakistan J. Biol. Sci., 11: 3246-2350.

Stevens RB. 1974. Mycology Guidebook Committee. Mycology Society of America. University of Washington Press, Seatle and London, pp 703.

Sundar AR, Das ND and Krishnaveni D. 1995. In vitro antagonism of Trichoderma sp. against two fungal pathogens of castor. Indian J. Pl. Prot. 23: 152-155.

Tagaram N, Rani AS, Hindumathi A and Reddy BN. 2015. In vitro evaluation of Trichoderma viride and Trichoderma harzianum for its efficacy against Alternaria alternata, the leaf spot pathogen on Senna plant. IOSR J. Pharm. Biol. Sci.10 (6): 145-147.

Tapwal A, Singh U, Jaime A, Silva T, Singh G, Garg S and Kumar R. 2011.In vitro antagonism of Trichoderma viride against five phytopathogens. Pest Technology. 5 (1): 59-62.

Vinale FK, Sivasithamparam EL, Ghisalberti R, Marra SL Woo and Lorito M. 2008. Trichoderma-plant-pathogen interactions. Soil Biol. Biochem. 40: 1-10.

\section{How to cite this article:}

Upamanya, G.K. and Pranab Dutta. 2019. Screening of Biocontrol Agents against Pathogens causing Diseases of Brinjal. Int.J.Curr.Microbiol.App.Sci. 8(06): 1232-1240.

doi: https://doi.org/10.20546/ijcmas.2019.806.150 